\title{
Business angel exits: a theory of planned behaviour perspective
}

\author{
Tiago Botelho $•$ Richard Harrison • Colin Mason (D)
}

\begin{abstract}
Although there are a handful of studies on business angel investment returns, the business angel literature has given little or no attention to exits and the exit strategy. This is surprising given that a primary objective of investing is to achieve a capital gain through some form of liquidity event. Using the theory of planned behaviour (TPB) as an interpretative heuristic, we examine how exits happen: specifically, what are the motivations to seek an exit and to what extent are they planned or opportunistic? Based on multiple case studies in which business angels were invited to tell the story of their most recent exit(s), the evidence suggests that the majority of liquidity events are the outcome of planned behaviour. We propose a typology of angel-backed investment exits as the basis for identifying future directions for research and developing practical advice to angels on effective business practices.
\end{abstract}

\section{T. Botelho}

Norwich Business School, University of East Anglia, Norwich, UK

\section{R. Harrison}

University of Edinburgh Management School, Edinburgh, UK

C. Mason $(\bowtie)$

Adam Smith Business School, University of Glasgow, Glasgow, Scotland, UK

e-mail: colin.mason@glasgow.ac.uk
Keywords Business angels $\cdot$ Harvest event . Entrepreneurial exit · Investment returns · Theory of planned behaviour

JEL Classification D91 · G23 · G24 · L26 · M13

\section{Introduction}

The exit is where you get your money back, you hope, with return, even better, and possibly a very good return, better still. (Cowley 2018) ${ }^{1}$

Keep in mind that angel investors invest for returns. $^{2}$

Business angels achieve their financial returns through exits. They make investments in early stage companies, usually taking a minority stake, and rely on the entrepreneurs they back to deliver value. But they only achieve a financial return when their shares are sold. This requires a 'liquidity event', normally through the acquisition of their investee company by another company. Moreover, they are looking for a large return. This is because early stage

\footnotetext{
${ }^{1}$ Peter Cowley is an active angel investor, having invested in over 65 start-ups. He was named UK Business Angel of the Year 2014/15 and Best Angel of the World by the World Business Angel Investment Forum in February 2017. In July 2018, he was elected President of the European Business Angels Network (EBAN) - the trade body representing the early stage investor and start-up community throughout Europe.

${ }^{2}$ Stephan Little: startups.ca
} 
investing is high risk so they need some of their investments to generate a substantial return to compensate for their other investments that either fail or perform just well enough to keep in business but not sufficiently well to be able to attract a buyer. Yet despite the centrality of the exit to business angel investing, it has been largely ignored in both the academic and practitioner literatures. Research on entrepreneurial exits (e.g. DeTienne 2010; Wennberg et al. 2010; DeTienne and Cardon 2012; Wennberg and DeTienne 2014) has taken an entrepreneur-centric perspective and ignored investor exits. And, as recent reviews of the business angel literature indicate, there have been few studies of the exit stage in the investment process (Edelman et al. 2017; Wallmeroth et al. 2018; Tenca et al. 2018), with these studies largely focused on investment returns (Mason and Harrison 2002; Wiltbank and Boeker 2007; Wiltbank 2009; Wiltbank et al. 2009; McDonald and DeGennaro 2016; Gregson et al. 2017). However, the process by which business angels achieve exits-specifically, the extent to which they were the outcome of a planned strategy or an opportunistic response to circumstances - represents an important question which we cannot answer at present. From a practitioner perspective, Basil Peters - a fund manager, angel investor and exit coach—observes that "exits are the least understood part of investing, as often by the investors themselves as by the entrepreneurs" (Peters 2009, p. 15).

Various studies have found that business angels give little thought to future exit routes, do not have exit plans at the time of investing and are relaxed about the timing of the exit (Wetzel 1981; Gaston 1989; Harrison and Mason 1992; Landström 1993; Mason and Harrison 1994; Lumme et al. 1998; Harrison et al. 2016). For example, Collewaert (2012, p. 755) comments that the "angel investor exit is often unplanned and many angels do not have a clear exit route preference." Indeed, a common view amongst business angels is that "good investments will find their own exits" (cited in Mason et al. 2016). Furthermore, helping to prepare the business for an exit is not a significant post-investment role that angels play in their investee companies (Politis 2008).

However, with the growing professionalisation of angel investing in the form of managed angel groups (Mason et al. 2013, 2016), more attention is now being given to the exit, particularly amongst the practitioner community (e.g. Peters 2009; McKaskill 2009; Mason et al. 2015). Angel groups - which typically have between 25 and 75 members but some have over 100 members - enable individual angels to invest collectively. Members have a wide range of industry backgrounds but are mostly entrepreneurs, business professionals and senior executives (Mason and Botelho 2014). A manager - who may be one of the members or a hired professional - typically undertakes the initial screening of investment opportunities and manages investor engagement. However, each business angel makes their own investment decisions. The emergence of angel groups reflects the need for greater financial resources to make larger investments, including follow-on investments, beyond what most individual angels would be willing to commit as the focus of venture capital funds has shifted to larger deals. Because of their greater financial resources, angel groups are more likely to fund their investments to an exit, via follow-on investments (Harrison et al. 2010). Angel groups are attractive to individual investors by offering superior deal flow and lowering the risk of investing by enabling them to achieve more diversified investment portfolios, providing access to better due diligence and more effective post-investment support and giving the opportunity to learn from more experienced investors (Mason et al. 2019). Groups appoint one of their members to act as a non-executive director in each investee company and provide appropriate hands-on support and advice (Mason et al. 2016). Angel groups are much more focused on exits than individual angels because of the need both to give their members liquidity to make further investments and to be able to attract new members (Mason et al. 2015). Entrepreneurs are also advised that they must be able to articulate an exit strategy in their pitches to angels (Loehr 2016; Berry n.d.). So, for these reasons, we would expect to see a more proactive emphasis on the exit process than in the past.

As the first attempt to open the exit 'black box', this paper follows the tradition adopted by Wetzel (1983) in his pioneering studies of business angels which had the objective of "putting boundaries on our ignorance". The paper asks the following research question: To what extent is the exit the outcome of a planned or an opportunistic strategy by an angel investor? We follow McDonald and DeGennaro (2016) in distinguishing between two types of 'termination events': (i) exits, which are outcomes in which the investor recovers all their original investment plus a premium (e.g. through an IPO, trade sale to third party investors or management share buy-back), and (ii) expirations, where the investment is written off or generates zero returns, typically as a result of the closure of the business.

This distinction recognises, a priori, that these two types of event are different in terms of investor 
intentions and behaviours. While investors aspire to achieve exits, and may act in such a way as to realise these aspirations, they do not aspire to, or work towards, expirations. Planning an exit is an integral part of a venture capitalist's decision to invest in an entrepreneurial firm (given the need to generate returns for the limited partners (LPs) in their funds), and the exit route is a joint decision (but also a potential point of difference or conflict) between the investor and entrepreneur (el Bouzaidi 2015, p. 90). For angel investors, who are not driven by the need to generate returns to LPs, generating positive returns (i.e. exits) is a key motivation for investing, but one which may be pursued passively rather than actively (Harrison et al. 2016). We also recognise that for most angel investors, exits and expirations represent only a minority of their investments, with a majority of their investee businesses generating sufficient revenues to stay in business but not performing well enough to attract a buyer. For example, Go Beyond, a European angel group based in Switzerland with members from 45 countries, has made investments in 98 companies since it started investing in 2008, achieving 9 successful exits; 10 investments had failed and 79 companies were still in their portfolio (Go Beyond 2019). In other words, exits - the intended outcome of angel investing - are relatively rare events.

While the general expectation of capital gains is a major driver of angel investing and can provide the opportunity and means to recycle resources into further investments, only around one-quarter of investors have a clear exit strategy at the point of making the investment and the exit is low on the list of influences on the investment decision (Landström 1998; Mason and Botelho 2016; Mason and Harrison 2003; Van Osnabrugge 1998). Furthermore, recent research has demonstrated that most investors are patient (that is, they have a long-term orientation in terms of holding period for their investments) by default, in the absence of exit opportunities, rather than intent (Harrison et al. 2016), implying an opportunistic rather than strategic approach to the exit. However, the exit process itself has not been subject to detailed scrutiny to date, a gap in our understanding of the angel investment process which this paper seeks to rectify. In doing so, we follow the call of Maula et al. (2005) for more research into angel investing from a theory of planned behaviour perspective. Accordingly, using the theory of planned behaviour (TPB) (Ajzen 1988, 1991) as an interpretative heuristic, we examine the argument that exits are the outcome of planned strategic decisions (Peters 2009; McKaskill 2009), drawing on evidence from 17 case studies of angel-backed companies where the angel was able to achieve an exit. On the basis of our exploratory analysis, we develop a typology of exits and highlight key research questions for future work.

\section{Literature review}

\subsection{Angel exits as planned behaviour}

The implication of adopting an exit-centric approach to investing is that it requires a commitment to carrying out an action or actions in the future and requires planning and forethought (Hayward et al. 2017). This, in turn, suggests that the exit process can be examined through the lens of the TPB (Ajzen 1988, 1991). This theory, an extension of the theory of reasoned action (Fishbein and Ajzen 1975), is an expectancy-value model of attitudebehaviour relationships which details the determinants of an individual's decision to enact a particular behaviour and is designed to provide parsimonious explanations of informational and motivational influences on behaviour (Conner and Armitage 1998). As a deliberative processing (cognition-based) model, TPB assumes that individuals make decisions based on careful considerations of the available information, and it specifically addresses behaviour or situations where individuals have incomplete ability or control to exercise their own will (Ajzen 1988, 1991, 2002). It proposes that volitional human behaviour is a proximal function of the individual's intention to perform the behaviour, where intentions represent the individual's motivation that is their conscious decision or plan to exert effort to enact the behaviour. Based on the principle of compatibility (Fishbein and Ajzen 1975), intentions and behaviour are strongly related when measured at the same level of specificity in regard to the action, target, context and timeframe and under the condition that the time interval between intention and behaviour is short enough to ensure that intentions have not changed (Conner and Armitage 1998). The TPB also addresses the predictability of nonvolitional behaviours by incorporating perceptions of the control over performance of the behaviour as a predictor. As such, the theory addresses not just easily performed volitional behaviours but also complex goals and outcomes "which are dependent upon performance of a complex series of other 
behaviours" (Conner and Armitage 1998, p. 1430). Echoing Bandura's (1982) self-efficacy construct, the theory posits that behaviour is a function of behavioural intentions and perceived behavioural control (PBC), the individual's perception of the extent to which performance of the behaviour is easy or difficult (Ajzen 1991) and their own ability to perform that behaviour. This control can be viewed as a continuum from easily executed behaviours at one end and those, such as the angel exit, requiring resources, opportunities and specialised skills at the other.

Our application of TPB as a perspective on angel exits is justified on two grounds. First, it identifies the central link between intentions and behaviour, which reflects the fact that people tend to engage in behaviours they intend to perform. In the case of angel investment, therefore, the intention to exit will be reflected in the investor engaging in exit behaviour - the exit will be a strategic choice, actively pursued. Second, the link between $\mathrm{PBC}$ and behaviour suggests individuals are more likely to engage in desirable behaviours over which they have control and will be prevented from enacting behaviours over which they have no control. Equally, subject to intentions being held constant, as PBC increases so the likelihood of the behaviour being performed will also increase. In the case of angel exits, $\mathrm{PBC}$ allows us to distinguish between those exits that are intentional and those that are driven by other interests, such as pressure from the founder or other investors (notably venture capitalists), where the angel might find the exit imposed on them. In this respect, it is apposite to note that angel research is ambivalent on the extent to which angel investors think in portfolio, rather than deal to deal, terms, although the rise in the significance of angel groups is likely to increase the prevalence of portfolio thinking (Gregson et al. 2013, 2017; Mason et al. 2016). Nevertheless, it remains the case that the exit is considered on an investment-specific basis and that typically the exit process will be led by the angel, for two reasons. First, angels typically invest at earlier stages than institutional investors, which helps to build a relationship with the entrepreneur. This will lead to the angel being the first external 'influence' on the entrepreneur's actions. Second, despite the possibility of conflict in the angel-entrepreneur relationship (Collewaert 2012), there is substantial evidence that angels want to achieve exits (Harrison et al. 2016) and that there is a very strong alignment between all agents involved (angels, entrepreneurs and other investors).
According to TPB, an individual's intentions are determined by their attitudes towards the behaviour, subjective norms and perceived control over the behaviour $(\mathrm{PBC})$. Each of these in turn has determinants (the indirect determinants of intentions). First, attitudes are the overall evaluations of the behaviour by the individual and specifically those towards performance of the behaviour. Attitude is in turn a function of the individual's salient behavioural beliefs, that is their perceived outcomes or attributes of the behaviour. In expectancyvalue terms, outcomes are the combination "of the perceived likelihood that performance of the behaviour will lead to a particular outcome and evaluation of that outcome" (Conner and Armitage 1998, p. 1431). Second, subjective norms comprise an individual's beliefs about whether significant others (those whose preferences about an individual's behaviour in this domain are important to them) think they should enact the behaviour. These subjective norms are assumed to represent the social pressures on individuals to perform or not perform a particular behaviour. These in turn are determined by normative beliefs, the perceptions of "specific significant others' preferences about whether one should or should not engage in the behaviour, ... the subjective likelihood that specific salient groups or individuals (referents) think the person should or should not perform the behaviour,... [and] ... the person's motivation to comply with that referent" (Conner and Armitage 1998, p. 1431-1432). This is particularly relevant in a business angel group context, where the investment decisions of individual members may be influenced by other investors (Mason et al. 2019). Here, the subjective norm captures the effect of other investors' views on a particular opportunity and/or action (e.g. invest, reinvest, exit, etc...). Third, PBC, the individual's perception of their own ability to perform that behaviour, is itself influenced by control beliefs concerning "whether one has access to the necessary resources and opportunities to perform the behaviour successfully, weighted by the perceived power of each factor to facilitate or inhibit behaviour" (Conner and Armitage 1998, p. 1432). These control beliefs can be internal control factors (e.g. information, skills, emotions, personal deficiencies) or external control factors (e.g. opportunities, barriers, dependence on others). Further, the degree to which PBC directly influences behaviour (rather than indirectly through intention) depends on the degree of actual control over the behaviour, and individuals who perceive that they have access to the necessary resources 
and believe that there are opportunities or lack of obstacles to perform the behaviour are likely to have high levels of PBC (Ajzen 1991).

As an illustration of how this might be applied to the angel exit process, consider the situation of a business in which the angel(s) is invested alongside an institutional $\mathrm{VC}$ investor. In such circumstances, there may be important legal concerns that limit the business angel's ability to exit, including tag-along rights, right of first refusal, and other shareholder consent requirements that might limit an individual business angel's management/behavioural options and exit opportunities. There may also be questions concerning the discount that the business angel might have to concede to realise the exit and valuation concerns as a signalling for future rounds. All of these external control factors would be reflected in a low PBC on the part of the angel investor.

The basic TPB model developed by Ajzen (1988) is shown in Fig. 1. In addition, TPB makes a number of mediating hypotheses. First, the effect of attitude and subjective norm on behaviour is fully, and that of PBC on behaviour, partially mediated by intention, such that as a general rule, the more favourable the attitude and the subjective norm, and the greater the perceived control, the stronger should the person's intention to perform the behaviour in question. Second, the effect of all other cultural, environmental, biological, social and economic influences is hypothesised to be mediated by the TPB, a sufficiency assumption that has been subject to some criticism (Sniehotta et al. 2014).

The TPB has been extensively applied in entrepreneurship research over the past 20 years or so (Fig. 2), primarily to examine entrepreneurial intentions in the venture creation context (Schlaegel and Koening 2014; Lortie and Castrogiovanni 2015). This is on the basis that entrepreneurial activity, such as the launch of a nascent business, is a planned event not a conditioned response to a stimulus (Krueger et al. 2000). It is, in other words, "an intentional process in which individuals cognitively plan to carry out the behaviours of opportunity recognition, venture creation, and venture development" (Lortie and Castrogiovanni 2015, p. 2). While much of the entrepreneurship applications of the TPB have cut up, compartmentalised and fragmented the theory (Lortie and Castrogiovanni 2015), there is general consensus that there is a link between intentions and subsequent behaviours (Schlaegel and Koening 2014; Armitage and Conner 2001). Specifically, the 42 papers reviewed by Lortie and Castrogiovanni (2015) do confirm the relationship between attitudes and intentions, PBC and intentions and intentions to behaviours. However, the link from subjective norms to intentions was rather less well supported. The one relationship that does not receive widespread attention in the entrepreneurship literature is that between PBC and behaviour. The one study reviewed that does find such support is a study of the role of PBC specifically on the decision to make an informal investment which concludes that attitudes, skills and experience are more important than investor demographics and suggests the TPB framework is therefore applicable in explaining informal investment behaviour (Maula et al. 2005). Very few studies in entrepreneurship have applied or tested TPB in its entirety: of the papers included in one recent review, $38 \%$ analysed the link between attitudes and intention, $33 \%$ that between subjective norms and intentions and $54 \%$ that between PBC and intentions; only $31 \%$ looked at the link between intentions and behaviour and only 7\% (3 papers) examined the non-mediated link between $\mathrm{PBC}$ and behaviour (Lortie and Castrogiovanni 2015). Furthermore, the majority of applications of TPB in entrepreneurship have focused on explaining intentions in the venture creation context, with fewer applications in the explanation of behaviour or in the context of venture development (Table 1) or wider entrepreneurial contexts such as opportunity recognition, innovation, angel investment, entrepreneurial networking and entrepreneurial turnover and exit (Ramos-Rodriguez et al. 2010; Montalvo 2006; Maula et al. 2005; Vissa 2011; Brigham et al. 2007). We add to this literature by using TPB as a lens to examine a behaviour - the business angel's exit strategy — not hitherto studied using this framework. In so doing, we are responding to calls for more entrepreneurship research to explore the connections between intentions and planning, to investigate more specifically the PBC-behaviour link and to make more use of qualitative approaches such as interviews (Lortie and Castrogiovanni 2015, p. 951).

Beyond entrepreneurship, there has been considerable criticism and debate over the methodology, validity and utility of the TPB (for example, see French and Hankins 2003; Sniehotta et al. 2014; Gollwitzer and Oettingen 2015; Schwarzer 2015; Rhodes 2015; Ajzen 2015; Hagger 2015; Armitage 2015; Connor 2015). Given this, we treat TPB as an interpretative heuristic, where the 'successful exit' is the problem to be explained and TPB is the heuristic to explain that. This follows approaches recommended in philosophy and the 
Fig. 1 The pure form of the theory of planned behaviour. Source: Shih and Fang (2004), adapted from (Ajzen 1988, 1991)

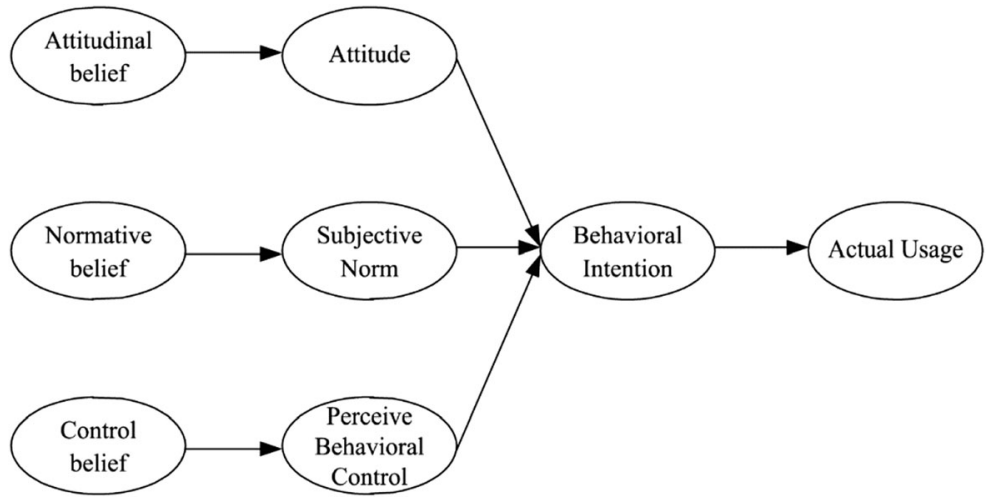

philosophy of science. Specifically, we follow Schwab $(1962,1974)$ in recognising that there is an important epistemological distinction between the methodological (empirical data) and interpretative (heuristic principles) components of scientific knowledge: given the incomplete treatment of TPB to date in the entrepreneurship literature, relative to other discipline areas, its use as an interpretative heuristic is justified. This is reinforced by the recognition, in an extension to Simon's (1990) bounded rationality argument, that the interpretative heuristic is central to problem solving: it is an adaptive characteristic of the human cognitive system which guarantees cognitive economy when meanings and relations are familiar, permitting their recognition. In situations where meanings and relations are unusual, and the usual interpretations will not work, the interpretative heuristic represents the exploration of other ways of interpreting the problem in a search for possible relations between the parts and the whole. As a result, "the original representation of the data changes when a new

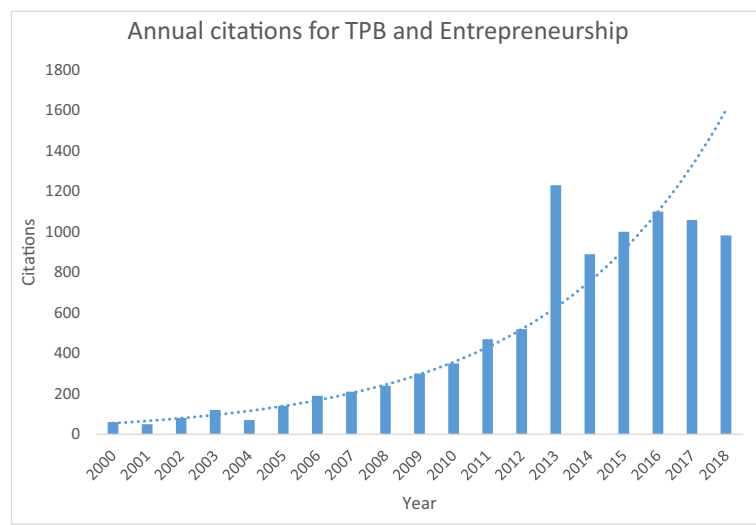

Fig. 2 Number of citations for "theory of planned behaviour" and entrepreneurship. Source: Google Scholar. Note: 2018 data correct up to October 2018 only relation is discovered, [...] The same data, seen in a different light, provide a view that is different to the default, the original starting point. [...] new relations are found by exploring different interpretations, and not by exhaustive searches or abstractions" (Macchi and Bagassi 2014, p. 106). As such, our approach to TPB in this paper is to use the theory to interpret the social world of the business angel investor. We treat the theory as a perspective, a "point of understanding to sort out the buzzing confusions and complexities of the social world" (Spicer 2008, p. 47). As such, the moment of doing theory becomes not one of establishing causal relations to predict behaviours and outcomes, but one of trying to generate a meaningful understanding of the business angel's world. It is, in other words, an effort to understand and recover their patterns of meaning and interpretation of actions, to root out the practical knowledge of the actors as they go through the social world (Spicer 2008).

\section{Research design}

The research follows a case study approach. This research strategy is commonly applied in social sciences (Berg and Lune 2004) and is prominent in the field of entrepreneurship (Neergaard and Ulhøi 2007). It is particularly useful for exploratory research where the goal is to identify the 'how' and the 'why' (Yin 2014). Eisenhardt (1989, p. 548-549) also advocates the use of case studies, and multiple case studies in particular, claiming that they are "particularly well suited to new research areas or research areas for which existing theory seems inadequate". Garg and Eisenhardt (2017) suggest that this approach is suitable when the researchers aim to understand a process question. 
Table 1 Domain applications of TPB in entrepreneurship (number of papers, $n=42$ )

\begin{tabular}{llll}
\hline & & \multicolumn{2}{c}{ Entrepreneurship category } \\
\cline { 3 - 4 } & & Venture creation & Venture development \\
\hline TPB category & Intentions & 21 & 2 \\
& Behaviours & 6 & 5 \\
\hline
\end{tabular}

Note: Only 36 papers are classified. The remainder include wider entrepreneurial contexts such as opportunity recognition, innovation, angel investment, entrepreneurial networking, and entrepreneurial turnover and exit (Ramos-Rodriguez et al. 2010; Montalvo 2006; Maula et al. 2005; Vissa 2011; Brigham et al. 2007). Source: Lortie and Castrogiovanni (2015)

There are various case study approaches. This study adopts a multiple-case holistic approach with one unit of analysis (Yin 2014) — the process of successfully exiting from an investment. According to Yin (2014, p. 50), this research design "is advantageous when no logical subunits can be identified or when the relevant theory underlying the case study is itself of a holistic nature". As noted previously, the exit process has been largely ignored in business angel research.

The unit of analysis and focus of the research is on the nature of the exit process in successful exits to identify what were the commonalities in terms of investor behaviour and how these influence the exit outcome. A first layer of study questions was designed to understand how exits are achieved in angel-backed companies and what is the role of business angels in the exit process. Hence, participants were asked to elaborate the process by which they thought about the exit (when, how, why, involvement, drivers). With the objective of achieving a deeper understanding of the exit process, a second layer of study questions was designed to focus on understanding if an exit is achieved through proactive strategy or is it opportunistic, and what influences the intention of being actively involved in achieving an exit. This second layer of questions had a strategic focus to: (i) understand how much the exit was the result of a particular strategy, (ii) identify the particular actions undertaken by participants as the exit process unfolds and (iii) comprehend how external factors (time, market conditions, funding options, etc.) can impact the angel investors' strategic decisions.

\subsection{Sample and data collection}

The choice of which cases to study is not a straightforward decision (Stake 2005). In this study, this decision was devolved to the participants who were asked to select and then talk through one or two of their most recent exits. The selection of cases was constrained by the general lack of exits by business angels. Our previous studies of angel group managers and individual angels had asked each of them how many exits they had achieved (Mason et al. 2013). This provided an initial sample of angels who had experienced an exit and were therefore potential participants in this stage of the study. We also examined the websites of angel groups to identify any exits that had been achieved. Additional angels were identified using snowballing sampling, defined by Biernacki and Waldorf (1981, p. 151) as a technique to "contact one participant via the other". Using these three approaches resulted in the identification of six angel groups and 16 individual angels with exits. Eisenhardt (1989) recognises that in case study research, random samples might be neither essential nor desirable; hence, this convenience sample should not be seen as a study limitation.

Four angel groups were contacted. The two other groups with exits were excluded for two reasons: (1) the nature of the investment was not a typical angel investment (property deal) and (2) the group had ceased its angel investment activities (transforming itself into a publicly listed investment fund). Three of the four groups agreed to take part in the research. The executive member responsible for that specific investment was interviewed. In total, the angel group investments accounted for six cases, derived from interviews with four angel group executives from three angel groups. The recruitment of individual angels had to satisfy the condition that the investor had played a leading role in the exited investment. Passive investors-by definition-would not have been in a position to influence a company's decisions and unlikely to be fully aware of the reasons behind the decisions made during the exit process. Four of the angels contacted satisfied this condition. Only one of these investors agreed to be interviewed. Five individual angels were recruited 
through snowballing. In summary, the study is based on a convenience sample of 17 case studies of exited investments, involving ten different investors. All of the investors were based in the UK.

Table 2 summarises the characteristics of the exited investments. It is clear that the sample is diverse as reflected in the control variables used, enabling us to gain rich insights on investors' behaviour. The ages of the oldest and youngest firms span a period of 15 years. They come from different industries. The stage at which the firms raised angel investment is consistent with previous studies (Mason and Harrison 2010, 2011), with approximately $40 \%$ of the firms funded at the start-up stage. Additionally, the average holding period to exit of this sample ( 7.25 years) is in line with previous studies. Sixteen of the 17 exits were achieved through trade sales which is also consistent with prior research (e.g. Mason and Harrison 2002).

\subsection{Case analysis}

The analysis follows previous research (Meyer 2001; Karlsen 2007) which uses a four-stage process that involves establishing the chronology, coding and writing up the data according to phases and themes, comparing the cases and applying the theory. Eisenhardt (1989) justifies this procedure as a way to accelerate cross-case appraisal.

In the first step, one of the authors organised the data of each case chronologically. This was done by categorising and numbering the different documents for each case. The following step was to code the data into themes that would reproduce the contextual factors. The coded statements were then grouped together under the appropriate themes. The themes used to code the data were derived from TPB. This thematic approach enabled the patterns emerging from each 'story' to be identified (Miles and Huberman 2003). The third step was to verify the differences and the commonalities across the cases. Eisenhardt (1989) justifies this practice to increase the fit between theory and data. The final step was to evaluate what had emerged in the previous stages with the current theory regarding business angel exits. This was achieved by analytic generalisation. Yin (2014, p. 31-33) describes this process as follows: "in analytic generalization, the investigator is striving to generalize a particular set of results to some broader theory". This approach is particularly useful when the objective is to generalise to a theory of a phenomenon being studied. However, this is not a search for statistical representativeness to generalise a rule that was found in the sample to a population. Rather, the rational for this approach is to link the findings with existing theory in order to contribute to a general theory of the topic (Becker 1990). Each case was independently analysed by at least two of the three authors, and the interpretations were then shared and further compared with the remaining cases.

Rowley (2002, p. 24) presents four principles that should be followed to help in the analysis of case studies. First, the analysis makes use of all the relevant evidence. Second, the analysis considers all of the major rival interpretations and explores each of them in turn. Third, the analysis should address the most significant aspect of the case study. Last, the analysis should draw on the prior expert knowledge of the researcher(s) in the area of the case study, but in an unbiased and objective manner. This set of procedures was adopted to enable an indepth understanding of the study findings. Additionally, representative quotes (power quotes in Pratt's (2008) terms) relating to the identified themes were used to help illustrate the results (Ryan and Bernard 2000). The contrasting perspectives of all participants were taken into account and discussed individually. This involved presenting every participant at the end at every interview with the set of interpretations that the research team had reached. This reduced the risk of missing rival interpretations. It is important to emphasise that this course of action helped not only to verify possible rival interpretations but also to develop a theoretical framework that is presented in the final section of the paper.

To increase the validity of results and minimise recall bias, the research design followed the suggestions of Miller et al. (1997). First, we asked for the most recent exit: the majority $(71 \%)$ occurring within the previous 5 years from the time of the interviews; second, during the interviews, in situations where participants did not recall the reasons for a decision they were encouraged to say that they did not remember. Additionally, the interview data were complemented by internal and external sources of information, when available, from company websites, angel group websites, newspapers, tech websites and Company's House to increase the reliability and validity of the research and enable the identification of any ex-post rationalisation by investors (Puhakka 2017; Vaivio 2008). 
Table 2 Characteristics of the case study exits

\begin{tabular}{|c|c|c|c|c|c|c|c|c|c|c|}
\hline Participant & Case & Started & Sector & Stage & $\begin{array}{l}£ \\
\text { invested }\end{array}$ & Investment & Exit & $\begin{array}{l}\text { Other } \\
\text { investors }^{\mathrm{a}}\end{array}$ & $\begin{array}{l}\text { Type of } \\
\text { exit }\end{array}$ & $\begin{array}{ll}\text { Multiple } & \text { Deal } \\
& \text { source }^{\mathrm{b}}\end{array}$ \\
\hline
\end{tabular}

(a) Investments by individual angels

\begin{tabular}{|c|c|c|c|c|c|c|c|c|c|c|c|}
\hline $\mathrm{P}_{2}$ & $\mathrm{C}_{3}$ & 2000 & $\begin{array}{l}\text { Software for mobile } \\
\text { and oil industry }\end{array}$ & $\begin{array}{r}\text { Growth } \\
\text { stage }\end{array}$ & $375 \mathrm{k}$ & 2011 & 2013 & $\mathrm{~B}$ & $\begin{array}{l}\text { Trade } \\
\text { sale }\end{array}$ & 2.1 & $\mathrm{PC}$ \\
\hline $\mathrm{P}_{2}$ & $\mathrm{C}_{4}$ & 1993 & Medical software & Seed & $40 \mathrm{k}$ & 1994 & 2006 & VC, CoIF & $\begin{array}{r}\text { Trade } \\
\text { sale }\end{array}$ & 25 & $\mathrm{PC}$ \\
\hline $\mathrm{P}_{3}$ & $\mathrm{C}_{5}$ & 2005 & Education & $\begin{array}{l}\text { Early } \\
\text { stage }\end{array}$ & $50 \mathrm{k}$ & 2007 & 2014 & BAs, CoIF & $\begin{array}{r}\text { Trade } \\
\text { sale }\end{array}$ & 4 & $\mathrm{PC}$ \\
\hline $\mathrm{P}_{3}$ & $\mathrm{C}_{6}$ & 2001 & $\begin{array}{l}\text { Software for mobile } \\
\text { industry }\end{array}$ & Start-up & $80 \mathrm{k}$ & 2001 & 2011 & BAs, CoIF & $\begin{array}{r}\text { Trade } \\
\text { sale }\end{array}$ & 8 & $\mathrm{PC}$ \\
\hline $\mathrm{P}_{7}$ & $\mathrm{C}_{11}$ & 1996 & Finance & Seed & $100 \mathrm{k}$ & 1997 & 2004 & BAs, B & $\begin{array}{r}\text { Trade } \\
\text { sale }\end{array}$ & 24 & $\mathrm{PC}$ \\
\hline $\mathrm{P}_{7}$ & $\mathrm{C}_{12}$ & 1995 & Industrials & $\begin{array}{l}\text { Early } \\
\text { stage }\end{array}$ & $275 \mathrm{k}$ & 2002 & 2012 & BAs, VC & $\begin{array}{r}\text { Trade } \\
\text { sale }\end{array}$ & 1.1 & $\mathrm{PC}$ \\
\hline $\mathrm{P}_{8}$ & $\mathrm{C}_{13}$ & 2003 & Software for mobile & Seed & $150 \mathrm{k}$ & 2004 & 2009 & $\begin{array}{l}\text { BAs, VC, } \\
\text { CoIF }\end{array}$ & $\begin{array}{r}\text { Trade } \\
\text { sale }\end{array}$ & 10 & PC \\
\hline $\mathrm{P}_{8}$ & $\mathrm{C}_{14}$ & 2006 & $\begin{array}{l}\text { Data software } \\
\text { management }\end{array}$ & Start-up & $175 \mathrm{k}$ & 2009 & 2014 & BAs, Corp & $\begin{array}{r}\text { Trade } \\
\text { sale }\end{array}$ & 6 & $\mathrm{AG}$ \\
\hline $\mathrm{P}_{9}$ & $\mathrm{C}_{15}$ & 2008 & $\begin{array}{l}\text { Software for } \\
\text { several industries }\end{array}$ & Seed & $50 \mathrm{k}$ & 2012 & 2016 & $\begin{array}{l}\text { BAs, VC, } \\
\text { CoIF }\end{array}$ & $\begin{array}{r}\text { Trade } \\
\text { sale }\end{array}$ & 7 & $\mathrm{PC}$ \\
\hline $\mathrm{P}_{9}$ & $\mathrm{C}_{16}$ & 2014 & $\begin{array}{l}\text { Machine learning } \\
\text { for real estate }\end{array}$ & Seed & $60 \mathrm{k}$ & 2015 & 2016 & BAs & $\begin{array}{r}\text { Trade } \\
\text { sale }\end{array}$ & 1.4 & PC \\
\hline $\mathrm{P}_{10}$ & $\mathrm{C}_{17}$ & 2010 & Health care & $\begin{array}{l}\text { Early } \\
\text { stage }\end{array}$ & $45 \mathrm{k}$ & 2012 & 2016 & BAs & $\begin{array}{r}\text { Trade } \\
\text { sale }\end{array}$ & 5 & $\mathrm{AG}$ \\
\hline \multicolumn{12}{|c|}{ (b) Investments by angel groups } \\
\hline $\mathrm{P}_{1}$ & $\mathrm{C}_{1}$ & 1994 & Hospitality & Seed & $>1 \mathrm{M}$ & 1994 & 2008 & CoIF & $\mathrm{MBO}$ & 1.2 & $\mathrm{AG}$ \\
\hline $\mathrm{P}_{1}$ & $\mathrm{C}_{2}$ & 2000 & Oil and gas & Start-up & $80 \mathrm{k}$ & 2000 & 2007 & BAs & $\begin{array}{l}\text { Trade } \\
\text { sale }\end{array}$ & 28.5 & $\mathrm{AG}$ \\
\hline $\mathrm{P}_{4}$ & $\mathrm{C}_{7}$ & 2001 & $\begin{array}{l}\text { IT services and } \\
\text { consulting }\end{array}$ & Start-up & $50 \mathrm{k}$ & 2006 & 2013 & CoIF & $\begin{array}{l}\text { Trade } \\
\text { sale }\end{array}$ & 8 & $\mathrm{AG}$ \\
\hline $\mathrm{P}_{5}$ & $\mathrm{C}_{8}$ & 2008 & Music & Seed & $1 \mathrm{M}$ & 2011 & 2013 & $\begin{array}{l}\text { BAs, } \\
\text { CoIF }\end{array}$ & $\begin{array}{r}\text { Trade } \\
\text { sale }\end{array}$ & 10 & $\mathrm{AG}$ \\
\hline $\mathrm{P}_{6}$ & $\mathrm{C}_{9}$ & 2001 & Bio-science & Start-up & $10 \mathrm{M}$ & 2003 & 2011 & $\mathrm{VC}$ & $\begin{array}{r}\text { Trade } \\
\text { sale }\end{array}$ & 1.2 & $\mathrm{AG}$ \\
\hline $\mathrm{P}_{6}$ & $\mathrm{C}_{10}$ & 2004 & Business services & Start-up & - & 2005 & 2014 & CoIF & $\begin{array}{r}\text { Trade } \\
\text { sale }\end{array}$ & 9 & $\mathrm{AG}$ \\
\hline
\end{tabular}

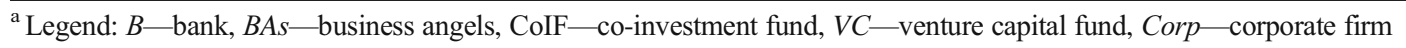

${ }^{\mathrm{b}}$ Legend: $A G$ —angel group, $P C$ - personal contacts

\section{Research findings}

The case studies were analysed around four themes that underpin TPB. The first theme, investor's intentions to exit an investment, is influenced by three factors. First is the attitude of investors towards the exit. Second, intentions to exit are influenced by subjective norms. This theme evaluates the investor's perception of social pressure (entrepreneurs, investors) to pursue the exit. The third theme is perceived behavioural control which assesses the investor's perception of their own capability to achieve the exit. All these factors were coded as themes.

\subsection{Attitudes}

Previous research has indicated that, contrary to much of the practitioner comment, business angels typically rate the exit as low as an investment criterion (e.g. Mason and Harrison 2003; Mason and Botelho 2016), and certainly much lower than venture capital fund managers do (Van Osnabrugge 2000). This is associated with the idea that business angels are providers of patient capital (Harrison et al. 2016). There is recent evidence that - perhaps surprisingly - most angel group managers also do not take a particularly exit-centric 
approach to their investing (Mason and Botelho 2016). Their approach was based on the 'folk wisdom', noted earlier, that if the investee business was successful, then there would be no difficulty in finding an exit (Mason et al. 2016). There is very little evidence to indicate when business angels do start to think about their exit or how deeply they think about it. Previous research is therefore unable to provide clear insights into the attitude of investors towards exit. This study indicates that in the great majority of the cases (14 out of 17 cases), angels have a favourable evaluation regarding the behaviour, that is, they did think about the exit at the start of the investment process, contrary to the evidence reviewed earlier. Investors recognised that they need to be able to anticipate an exit before investing:

We would not have invested without having an exit in mind. $\left(\mathrm{C}_{2}\right)$

You can't invest in something before you've thought about how you're going to get out. $\left(\mathrm{C}_{3}\right)$ Yes, I thought about the exit, I thought I would take it to AIM. $\left(\mathrm{C}_{12}\right)$

In just one case, the investor took a contrary view arguing that rather than focusing on the exit, investors should be mainly focused on creating value.

I never go into these things with an exit in mind. I know everybody says you should but I don't do that.... I don't think of the exit. I think of building value. $\left(\mathrm{C}_{8}\right)$

In the two other cases, the investors had a neutral attitude towards the exit. One investor observed that the choice of growing the company and creating value might be easier than thinking about the exit. "The market had not developed; the market that was going to buy us had not developed at that stage so we did not know how to get out. We thought we had a very good investment." $\left(\mathrm{C}_{11}\right)$. The other angel observed that a focus on growing the business is not inconsistent with being exitfocused because "you always think about the exit. You may not call it that but you are always designing businesses to be attractive to buyers" $\left(\mathrm{C}_{9}\right)$. This suggests that some investors have a neutral attitude about the exit because they are focused on building the business. However, this behaviour might be expected, in the longer term, to achieve the desired outcome of an exit.

In summary, in the majority of cases (14 out of 17 cases), investors exhibited a positive attitude towards achieving an exit. The drivers for this positive attitude are related to their desire to recover their investment and achieve a financial return. However, external factors (e.g. market development) can impact the attitude of investors towards the behaviour. The attitude of business angels towards exits can be neutral or negative if they consider that focusing on an exit will make them lose attention on growing the business. This adds to the notion of "patient by default" proposed by Harrison et al. (2016), that is, the lack of exit focus by angel investors does not mean that they do not have a positive attitude regarding pursuing an exit, it just means that they do not prioritise the liquidity event.

\subsection{Subjective norms}

According to the TPB, intentions are influenced by subjective norms, that is, how social pressure can impact the individual's intentions to perform a specific behaviour. The angel is not the only actor involved in the exit. Their intention to exit is therefore likely to be influenced by the views of the entrepreneur and also by any coinvestors. In the majority of the cases (15 out of 17 cases), the investor emphasised the importance of having the entrepreneur aligned with the angel on the intention to exit. Indeed, a lack of alignment is likely to be a 'deal killer' for exit-centric investors (Mason and Botelho 2016), making it unlikely that the investment would go ahead, and represents a significant source of post-investment conflict (Collewaert 2012). It is therefore not surprising to find a reported alignment of interests regarding the exit in all of the cases. However, as the following quotes show, the role of the entrepreneur can vary between, on the one hand, driving the exit and, on the other hand, simply agreeing with it.

They were keen. Yes. I mean, you should bear in mind we were actively involved. $\left(\mathrm{C}_{1}\right)$

Well, (the entrepreneurs) always started a business with an exit in mind. $\left(\mathrm{C}_{6}\right)$

They were positive. Bear in mind that the team were academics. They got a big cheque and were really happy. $\left(\mathrm{C}_{15}\right)$

They saw it as something they were very happy with. $\left(\mathrm{C}_{17}\right)$

There were only two cases where the entrepreneurs did not have a positive impact on the angel's perception of achieving an exit. However, these non-positive views 
did not seem to have a significant impact on the subjective norm of the investor since it did not change their intention to exit. In one case, the angel commented as follows:

I think they (the management team) were a little bit disappointed. ..... I think they probably felt they wanted to build a bigger company. $\left(\mathrm{C}_{8}\right)$

Business angels often invest alongside other investors or their investee businesses may raise follow-on finance from other investors. This means that business angels typically interact with other investors, such as venture capital funds, in their investee companies (Meglio et al. 2017; Zhang et al. 2011). Hence, a second dimension of subjective norm measures how other investors impacted the angel's intention of achieving an exit. All the exit cases included at least one additional investor (see Table 1). In the majority of cases (13 out of 17 cases), these investors also had a positive impact on the angel's subjective norm regarding the exit.

Other investors like $\mathrm{X}$ (business angel) just said you do it and let me know what the answer is. $\left(\mathrm{C}_{2}\right)$ The VCs played a significant role alongside the angels on achieving the exit. $\left(\mathrm{C}_{13}\right)$

The other investors were also on the board so they were very supportive. $\left(\mathrm{C}_{15}\right)$

However, the effect of other investors was not always as positive. In 4 of the 17 exits, the impact of other investors on the subject norm was neutral. In two cases, this was due to the lack of involvement (exit or postinvestment) from the other investors.

They (the Co-fund) were not involved. I felt they had nothing to say about the exit. $\left(\mathrm{C}_{1}\right)$

The whole deal could have been made without them (corporate firm), their position (5\%) was immaterial. $\left(\mathrm{C}_{14}\right)$

This evidence indicates that the intentions of business angels to achieve an exit are positively impacted by social pressure. In the majority of cases, both the entrepreneurs (14 out of 17 cases) and co-investors (13 out of 17 cases) have a positive impact on the views of angels about the exit. When business angels feel that other actors also want an exit, this serves to validate their own exit intentions. This supports Collewaert's (2012) work on how interactions between entrepreneurs and angel investors can positively impact exit intentions. This study extends this conclusion by highlighting that other investors can also have a positive effect on angels' intention to exit.

\subsection{Perceived behavioural control}

In TPB, the measure of an individual's perception of their aptitude to execute a specific task is understood as perceived behavioural control. This research evaluated this factor at two levels: (i) to what extent did the angels believe they were in control of the exit process (i.e. how much, if any, external support was necessary to achieve an exit); and (ii) how difficult was it to realise an exit (i.e. what challenges did the angel encounter in the exit process)?

In a majority of cases ( 9 out of 17 cases), the business angels were positive about their ability to achieve the exit. Typically, angel investors were of the view that they could be helpful in the exit process. These contributions occur at different stages of the exit process.

We got one of our investors involved to help them (management team) get ready for an exit. $\left(\mathrm{C}_{2}\right)$ $\mathrm{Me}$ and my fellow non-executive director, the finance guy, have been playing good cop bad cop in the negotiation process. $\left(\mathrm{C}_{5}\right)$

We (angels) approached the buyer and were successful. Angel $\mathrm{Y}$ did the introduction, angel $\mathrm{X}$ and I did most of the selling. $\left(\mathrm{C}_{11}\right)$

However, in a significant minority of cases (8 out of 17 cases), investors had negative attitudes about their ability to help the investee company to achieve an exit. In these cases, investors felt that they needed external support to be able to achieve the exit as they did not have the requisite knowledge, network or ability (Frey et al. 2011). The most common type of support was therefore to bring in external expertise that had the capability to identify and introduce a buyer for the company.

The company appointed a non-executive who was a deal maker, he was very instrumental when we did the sale. $\left(\mathrm{C}_{4}\right)$

Basically, at that stage a corporate financier was retained by the Board and they helped to drive the process. $\left(\mathrm{C}_{8}\right)$

We had a considerable help from an USA corporate finance boutique to ensure that we had more 
than one buyer. We wanted to have a bidding war. $\left(\mathrm{C}_{14}\right)$

This evidence indicates that although in the majority of cases the business angels considered themselves capable of helping in an exit process, there were a significant number of situations where angels had a negative perception of their ability to perform the task. In these situations, external expertise was sought.

The second measure used to evaluate perceived behavioural control was the difficulty that angels experienced in performing the task of achieving an exit. Typically, angels had positive views about the challenges of achieving exit. In 10 of the 17 cases, the angels made positive comments about the exit process.

The intention was to continue to build the business and essentially find an exit at some point, but it just helped. $\left(\mathrm{C}_{5}\right)$

I was not worried about the exit, I could not see what that exit was going to be but it was clear to see that an exit would happen given the scale opportunity. $\left(\mathrm{C}_{13}\right)$

There was a thought of an exit when the Spanish corporate came on board but then in a trade show we met the final buyer, we felt it was so easy to attract interest. $\left(\mathrm{C}_{14}\right)$

However, in seven of the cases (41\%), investors had a negative view about the exit process, seeing it as being a considerable challenge. There are various reasons why they held such views. In some cases, the investors considered that it took too long to achieve the exit

We were trying to get out for a long time, remember, we did tried to sell it in $97 / 98$ (ten years earlier). $\left(\mathrm{C}_{1}\right)$

It was profitable, but it was just very difficult to achieve. An easier exit would have been achieved by changing the strategy on the business about three years before we sold it. $\left(\mathrm{C}_{9}\right)$

The exit in this case would always have been more likely a trade sale. We did actually explore some other mergers earlier on when it became obvious that, actually, to grow it was hard because it was such a regulated environment. $\left(\mathrm{C}_{17}\right)$

This evidence clearly indicates that perceived behavioural control is the weaker factor influencing the intentions to exit. Not only do many investors perceive the exit process to be hard but they also do not feel prepared to deal with it. Even in successful exits, some investors had a negative perception about their ability to perform the task. This can be explained by the complexity and uncertainty associated to the exit process (Wennberg and DeTienne 2014).

\subsection{Intention}

In TPB, intention is assumed to be the immediate antecedent of behaviour. Ajzen (1991) observed that "the stronger the intention to engage in a behaviour, the more likely should be its performance" (p. 181). In this study, angels have performed the behaviour; hence, it could mean that they had positive intentions regarding an exit. In the majority of cases (12 out of 17 cases), this was confirmed: investors had a clear positive intention to exit the investment before performing the behaviour.

We had been trying to get out for a long time. And our target was there. $\left(\mathrm{C}_{1}\right)$

Well, we wanted to be aligned with management and management wanted an exit. And we wanted an exit because you've got to have some exits. $\left(\mathrm{C}_{2}\right)$

The company was exitable, that is, it was acquirable and we wanted to exit...ultimately as an angel investor you need your money back. $\left(\mathrm{C}_{14}\right)$

Some exits (5 of 17) were made reluctantly in order to solve a problem with the investment. Ajzen (1991) observes that intentions will match behaviour only when the behaviour is under volitional control, a situation in which an individual can decide what to do. In two cases, the investors indicated that they did not intend to exit, although as an exit was achieved, it was not unwelcome. One situation in which this lack of volitional control could arise is a conflict between the entrepreneur and the angel, prompting the angel to seek an exit even though there was no desire to do so:

It was either the CEO or myself leaving the company and I thought it would be better for the company for him to stay. $\left(\mathrm{C}_{12}\right)$

The entrepreneurs copped out, they thought they were not going to be able to grow the business. This was disappointing. $\left(\mathrm{C}_{16}\right)$

The lack of financial alternatives to meet the funding needs of the business also is another factor that may also 
prompt an angel to seek an exit even though this was not desired.

We were trying to raise money to ramp up production and it was really hard to because we could not get debt funding. $\left(\mathrm{C}_{8}\right)$

They knew, as I did, that the business was not delivering and to take it to profitability would have required a substantially greater investment. ... So, we knew between us we had no choice but to sell it. $\left(\mathrm{C}_{9}\right)$

The exit, in the end, was one that was brought about by necessity rather than a plan; they just need big bugs to overcome the regulated environment. $\left(\mathrm{C}_{17}\right)$

In summary, in the great majority of cases, angel investors had positive intentions to achieve an exit. However, in a minority of cases ( 3 out of 17), business angels did not have the intention to exit but were pushed to do so by other factors. Performing this behaviour without having an intention to do so is associated with the uncertainty of the entrepreneurial process which gives investors no option other than to exit (e.g. unmet funding requirements, de-motivated entrepreneurs, conflicts between investors and entrepreneurs, etc).

\subsection{Summary}

The influence of each of the dimensions of TPB is summarised in Table 3. It is clear that the factor with the lowest positive effect is perceived behavioural control. Indeed, this is the only dimension where there is not a strong positive effect. The explanation for this may be that angels consider exits to be difficult to achieve and doubt their ability to achieve this outcome. This evidence that angels demonstrate both lack of efficacy and unfavourable facilitating conditions suggests the merits of adopting in future research a decomposed TPB (Fig. $3)$. Based on the argument that belief structures are not monolithic, a decomposed TPB has been proposed (Taylor and Todd 1995) as the basis for making clearer the relationships involved (Fig. 3). Attitudinal belief structures are seen as the outcome of relative advantage (the benefits to the investor, such that the higher the benefits, the stronger the attitude), complexity (the degree to which the exit is perceived to be difficult, where complexity is negatively related to behaviour) and compatibility (the degree to which the exit fits with the
Table 3 Fit of theory of planned behaviour

\begin{tabular}{|c|c|c|c|c|c|c|}
\hline & \multicolumn{2}{|c|}{ Positive } & \multicolumn{2}{|c|}{ Neutral } & \multicolumn{2}{|c|}{ Negative } \\
\hline & $n$ & $\%$ & $n$ & $\%$ & $n$ & $\%$ \\
\hline \multicolumn{7}{|l|}{ Attitude } \\
\hline Exit process & 14 & 82 & 2 & 12 & 1 & 6 \\
\hline \multicolumn{7}{|l|}{ Subjective norm } \\
\hline Entrepreneurs & 15 & 88 & 2 & 12 & 0 & 0 \\
\hline Other investors & 13 & 76 & 4 & 24 & 0 & 0 \\
\hline \multicolumn{7}{|c|}{ Perceived behavioural control } \\
\hline Involvement & 9 & 53 & 0 & 0 & 8 & 47 \\
\hline Difficult & 10 & 59 & 0 & 0 & 7 & 41 \\
\hline \multicolumn{7}{|l|}{ Intentions } \\
\hline To exit & 12 & 71 & 2 & 12 & 3 & 18 \\
\hline
\end{tabular}

angel's existing values, previous experience and current needs). Subjective norms will be influenced by a range of normative influences; to the extent that there are substantial differences of opinion amongst significant referents, the influence of subjective norms on intentions will vary. Finally, and following Ajzen's (1988, 1991) original formulation, PBC can be decomposed into facilitating conditions (externally based resource constraints, time and money) and self-efficacy (the internally related dimension related to ability or perceived self-efficacy).

Our findings extend our current knowledge on the way business angels look at exits, in particular, demonstrating that the majority of positive exits are planned decisions. However, while providing new evidence on the place of these four themes in the exit process, it leaves unanswered the question if exits are achieved as a result of a proactive strategy by the angel. The next section therefore examines the activities that angels undertake to facilitate the exit.

\subsection{Exit strategy: proactive vs. opportunistic}

The practitioner literature suggests that business angels can increase the likelihood of an exit through the adoption of an exit-centric strategy (Mason et al. 2015). But there is no evidence on the extent to which successful exits are the result of proactive exit strategies. In a majority of the cases analysed in this study (10 out of 17), the investor had a proactive approach towards the exit. This is defined as the set of actions designed to prepare a venture to be 'exitable'. In this approach, the entrepreneur and the investor(s) take active steps to 
achieve an exit, such as signalling to the market they are an acquisition target, identifying a potential buyer and developing close relationships with external stakeholders.

I mean, one of the best ways of getting an exit is if the management pick up the word on the grapevine that some companies have cash and others haven't got, and they are buying or not buying. $\left(\mathrm{C}_{1}\right)$

We spoke to all the people. We spoke to a potential buyer, obviously, and we gave them a very clear steer that said 'look we are going to get bought. $\left(\mathrm{C}_{4}\right)$

Quite often, a good way of getting an exit is to have a partnership first to see if you can work together. Get them excited. Get them seeing the reason why they should buy. $\left(\mathrm{C}_{13}\right)$

An alternative course of action is the opportunistic approach. This is defined as a set of actions that have the objective of making the venture as appealing as possible to potential buyers but without taking actions, like those discussed above, to proactively seek a buyer. In this approach, the priority of both the entrepreneur and the investor(s) is to grow the business rather than seeking an exit but with the expectation that in due course this will attract interest from potential acquirers Typically, this strategy puts the investee business in the position of relying on an approach from a buyer instead of looking for an exit.

Well we weren't really thinking about it [an exit] as such. I mean the intention was just to build the business. ... The intention was to continue to build the business and essentially find an exit at some point, but there was no particular time table on that. $\left(\mathrm{C}_{5}\right)$

We always think about the exit. But the way this one happened was it was opportunistic in the sense that the buyer appeared out of nowhere. $\left(\mathrm{C}_{10}\right)$

The exit came to us because we had a business that was attractive. ...it had been made attractive and that's the key part of strategic planning, you have to make things that buyers want to buy. $\left(\mathrm{C}_{14}\right)$

In summary, a proactive exit strategy comprises a combination of strategic actions to identify and attract a specific buyer or buyers for the company. In this approach, the entrepreneur and the investor(s) are driven by the thought of achieving an exit. An opportunisitic strategy is defined as the set of actions that have the objective of growing the venture and, as a result, making it as appealing as possible to potential buyers. In this approach, the entrepreneur and the investor(s) are driven by the thought of growing the business rather than achieving an exit. An opportunistic approach can be a viable alternative to a proactive exit strategy as a means of achieving an exit (Fig. 4). This generates two further questions. What is the impact of these different strategies in terms of financial returns? And, what is the effect of having positive intentions to perform the behaviour in terms of return? These issues are considered in the next section.

\subsection{Typology of exits}

It is clear from the preceding discussion that exits occur in a variety of circumstances, for various reasons and with varying outcomes. As a conceptual contribution, this final section of the paper proposes a typology of angel-backed investment exits. The variables chosen reflect both the theoretical framework used in this study as well as the strategies that emerged from the data: the intentions to exit and the strategy undertaken by the angel. The exit intentions were divided into two groups: intended (positive intention) and unintended (neutral or negative intention). The strategy undertaken is defined as before: proactive or opportunistic. This is summarised in Fig. 5. The clusters are also profiled in terms of average returns and holding period. These profiles enable a comparison to be made across exit strategies and exit motivations.

The first cluster comprises all of the investments where the exit was intended by the angel investors and the angel adopted a proactive exit strategy. This is the classic planned exit. The exits in this cluster had returns that ranged from 1.2 to 28.5 times the initial investment, with an average return of 14.11 times. The average holding period was 8.14 years. The second cluster represents the investments where the business angel had the intention to exit but had an opportunistic strategy. In this case, the investor intended to seek an exit but the strategy that followed was to grow the venture rather focusing on the exit. This type of exit had returns that ranged from 4 to 9 times the initial investment, with an average return of 6.8 times. The average holding period of these investments was 6.4 years. 
Fig. 3 Theory of planned behaviour with belief decomposition and crossover effects. Source: Shih and Fang (2004), based on Taylor and Todd (1995)

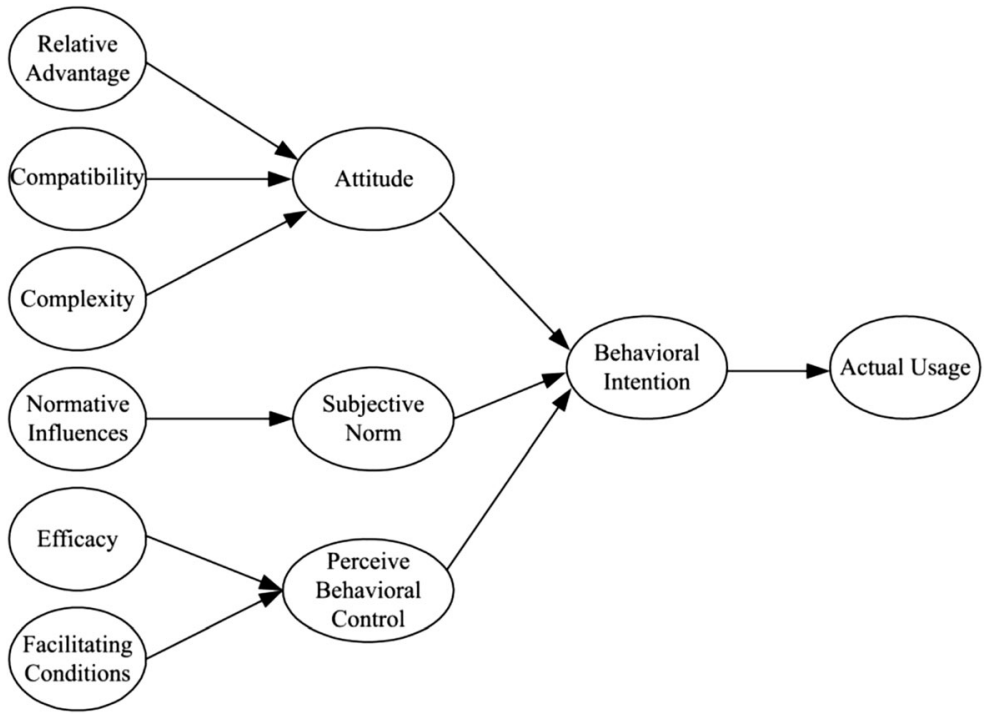

The third cluster comprised investments where the angel had a proactive exit strategy but had no intention to exit the investment. In other words, the investor was not seeking an exit at that that point in time, but was preparing the venture to achieve an exit at a later point in time. This was typically the result of circumstances dictating the need for an urgent exit. There were three cases of this type of exit. The average return for this group of investments was 1.23 times with a holding period of 6.33 years.

The final cluster comprised investments where the angel had no intention to exit but was able to achieve an opportunistic exit. These exits were therefore an unintended outcome of a strategy focused on growth rather than exit. There were only two cases of this type of exit. The average return was 7.5 times the investment and the holding period was 3 years.

It is significant that the cluster with the highest average return is the one where the angels had both the intention to achieve an exit and adopted a proactive exit strategy.
This seems intuitive: angels are rewarded for preparing an exit and searching for a buyer with a higher return. If the objective is to minimise the holding period, then an opportunistic strategy combined with no intention to exit at that particular point in time appears to be the best combination. In these cases, the angel did not make this strategic decision but was forced to exit because of funding difficulties faced by the investee firms.

\section{Conclusion}

This is the first research study to examine how exits by business angels occur. It supports the proposition that TPB is a suitable theoretical framework to conceptualise the exit process of angel investments. The evidence shows, first, that exits are in most cases the outcome of planned behaviour, and second, that most angels have adopted a proactive exit strategy, often developing close links with companies identified as being potential

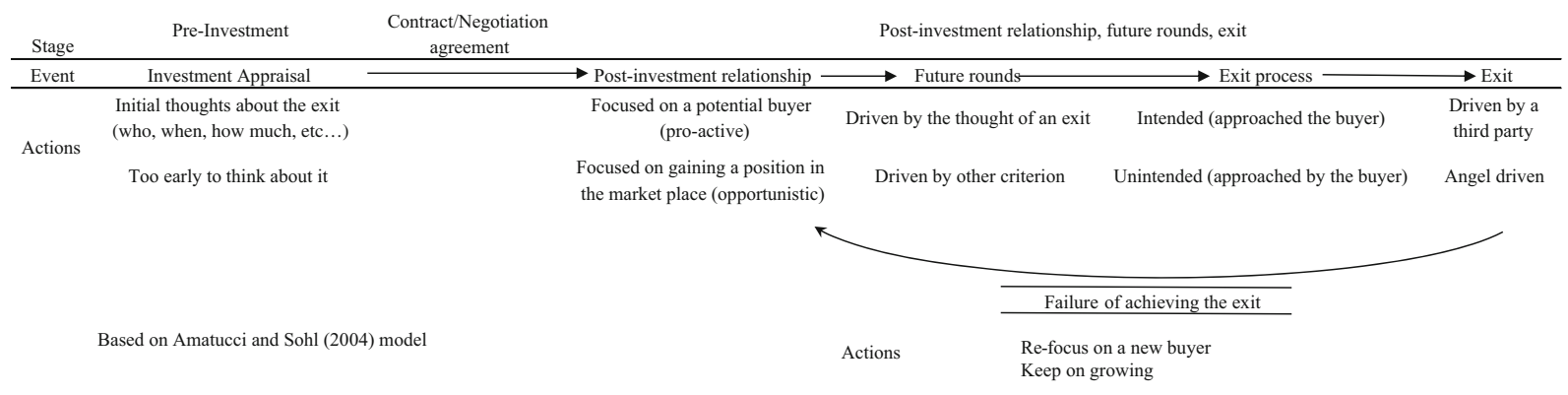

Fig. 4 Business angels' investment process, exit strategies and actions 
Fig. 5 Categorisation of angel exits

\section{Strategy}

Pro-active

Opportunistic

\begin{tabular}{|l|l|}
\hline Cluster 1 & Cluster 2 \\
$\mathrm{C}_{1}, \mathrm{C}_{2}, \mathrm{C}_{3}, \mathrm{C}_{4}, \mathrm{C}_{6}, \mathrm{C}_{11}, \mathrm{C}_{13}$ & $\mathrm{C}_{5}, \mathrm{C}_{7}, \mathrm{C}_{10}, \mathrm{C}_{14}, \mathrm{C}_{15}$ \\
\hline Cluster 3 & Cluster 4 \\
$\mathrm{C}_{9}, \mathrm{C}_{12}, \mathrm{C}_{16}$ & $\mathrm{C}_{8}, \mathrm{C}_{17}$ \\
\hline
\end{tabular}

acquirers. However, some exits are opportunistic and can occur even though an investor has no intention of achieving such an outcome at that time and following an unsolicited approach by an interested buyer. In these cases, investors might be forced into an exit because of factors that are either internal or external to the investee business, or may simply be due to investment fatigue. The study also indicates that a key reason why business angels do not adopt an exit-centric approach to their investments is because of low PBC-in other words, they attribute a high level of complexity to the task and therefore develop a lack of confidence to perform it.

We re-emphasise that our application of TPB is as a heuristic device, used to provide the basis for understanding of the business angel exit decision-making process, not as an explanatory framework which we formally test. However, our conclusions are consistent with recent longitudinal research which goes beyond the expanding stream of scholarship (see Lortie and Castrogiovanni 2015) explaining the formation of entrepreneurial intentions to examine whether the intention to start a business measured at one point of time translates into subsequent entrepreneurial behaviour (Kautonen et al. 2013). Their results support the predictions outlined in the TPB: first, attitude, perceived behavioural control and subjective norms are significant predictors of entrepreneurial intention; and second, intention and perceived behavioural control are significant predictors of subsequent behaviour. Kautonen et al. (2013) conclude that their research supports the application of TPB and the concept of behavioural intention to understand the emergence of complex economic behaviour such as entrepreneurial exits prior to the onset of any observable action (Kautonen et al. 2013). This conclusion is significant for the policy community given the importance of exits for the state as investor (Munari and Toschi 2014). In our discussion, we recognise that while the exit may be intended by the angel investor, and those intentions may indeed be shaped according to the TPB (although our results show a relatively weak relation between perceived behaviour control and intentions), investors may not have control over the timing of that exit. In other words, in Ajzen's (1991) terms, actual (rather than perceived) behavioural control may be a significant influence on the conversion of intention into behaviour. One of the challenges for entrepreneurship research seeking to develop and use TPB as a framework is the adequate operationalisation of the relationship between intentions and behaviour: we have, to a greater or lesser extent, a viable TPB-based theory of entrepreneurial intentions (Krueger and Carsrud 1993; Brännback et al. 2017); we do not yet have a fully specified TPBbased theory of entrepreneurial intentions and behaviour. For research in this vein to continue, there is a need to address the issue of research design and methodology posed by longitudinal research and also respond to the challenge of specifying, conceptually and operationally, the constituent elements of 'actual behavioural control'.

By following this strategy, it will be possible to address three obvious limitations of the present study. First, it is based on a small number of cases. While small number of cross-case comparison research designs can have explanatory power (Garg and Eisenhardt 2017), a larger sample would illuminate more aspects of the process, especially the role of actual behavioural control. Further work should therefore be undertaken on exploring business angel views on the exit process. Second, it is based entirely on the angels' view of the exit. Future research should seek to triangulate the views of angels with those of the entrepreneurs and the executives of the acquiring firm to assess the dynamic inter-relationships amongst the various parties involved (particularly around the congruence of interests, conflict and goal alignment), which are important in understanding the relationship between intentions and outcomes. Third, it only looked at successful outcomes - investments 
that achieved a positive financial return. Angels also have investments from which they have not exited; these are likely to be dominated by 'zombie companies' that are performing sufficiently well to survive but with no prospect of attracting a buyer. This raises further questions that future research needs to address. First, do different outcomes reflect the situationally specific operation of actual behavioural control or the adoption of an entirely different exit strategy? Second, although intention models such as TPB allow us to better understand the impact of various antecedents of entrepreneurial behaviour, identifying not only what influences this, but also how (Krueger and Carsrud 1993), they stop short of actually accounting for behaviour itself. It is therefore also necessary to develop to the same level our understanding of the specifics of the relation between intentions and behaviour. Third, our analysis focuses on the behaviour of the angel investor to achieve an exit rather than the processual actions required for the process itself to unfold. Hence, future research into the role of the investor in the exit process should adopt a processbased framework (Hjorth et al. 2015).

The study also has implications for practice. First, it provides empirical support for the growing emphasis in the practitioner literature on the need for investors to adopt an exit-centric investment strategy with a proactive approach to the exit. Not only is this the way in which the majority of exits occur, but it also generates the highest average returns. Second, it highlights the need for angels' associations and support organisations to provide angels with training on exits. ${ }^{3}$

Acknowledgements We are grateful to all of our interviewees for giving up their time to talk to us.

Funding information This paper arises from research funded by the ESRC under its Co-Funded Pilot scheme (ref: ESRC/BSB/ 08). The co-funders were NESTA, BVCA, Lloyds-TSB and Invest NI.

Open Access This article is distributed under the terms of the Creative Commons Attribution 4.0 International License (http:// creativecommons.org/licenses/by/4.0/), which permits unrestricted use, distribution, and reproduction in any medium, provided you give appropriate credit to the original author(s) and the source, provide a link to the Creative Commons license, and indicate if changes were made.

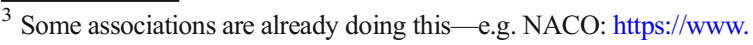
nacocanada.com/down/eJWFwQEKgCAMAMAXbZqmSb8 ZzVGUKW0Q9PrudrOhq3N6XKcaPYYakRp9@aZXcevN1 VCLiGTwIRLM7CsQ5wQp!aVEnliYcbD831cYig==/Module-108Exit-Strategies-Module-Description_External1.pdf
}

\section{References}

Ajzen, I. (1988). Attitudes, personality and behaviour. Milton Keynes: Open University Press.

Ajzen, I. (1991). The theory of planned behaviour. Organizational Behaviour and Human Decision Processes, 50, 179.

Ajzen, I. (2002). Perceived behavioural control, self-efficacy, locus of control, and the theory of planned behaviour. Journal of Applied Social Psychology, 32(4), 665-683.

Ajzen, I. (2015). The theory of planned behaviour is alive and well, and not ready to retire: a commentary on Sniehotta, Presseau and Araújo-Suares. Health Psychology Review, 9, 131-137.

Amatucci, F.M., \& Sohl, J.E. (2004). Women entrepreneurs securing business angel financing: Tales from the field. Venture Capital: an international journal of entrepreneurial finance, 6 , 181-196

Armitage, C. J. (2015). Time to retire the theory of planned behaviour? A commentary on Sniehotta, Presseau and Araújo-Suares. Health Psychology Review, 9, 151-155.

Armitage, C. J., \& Conner, M. (2001). Efficacy of the theory of planned behaviour: a meta-analytic review. British Journal of Social Psychology, 40(4), 471.

Bandura, A. (1982). Self-efficacy mechanism in human agency. American Psychologist, 37, 122-147.

Becker, H. S. (1990). Generalizing from case studies. In E. W. Eisner \& A. Peshkin (Eds.), Qualitative inquiry in education: the continuing debate (pp. 233-242). New York: Teachers College Press.

Berg, B. L., \& Lune, H. (2004). Qualitative research methods for the social sciences (Vol. 5). Boston: Pearson.

Berry, T. (n.d.). What startups need to know about exit strategies. https://articles.bplans.com/what-startups-need-to-knowabout-exit-strategies/

Biernacki, P., \& Waldorf, D. (1981). Snowball sampling: problems and techniques of chain referral sampling. Sociological Methods \& Research, 10(2), 141-163.

Brännback, M., Nikou, S., Carsrud, A. L., \& Hechavarria, D. (2017). Context, cognition and female entrepreneurial intentions: it is all about perceived behavioural control. In P. G. Greene \& C. G. Brush (Eds.), A research agenda for women and entrepreneurship. Identity through aspirations, behaviours, and confidence (pp. 169-186). Cheltenham: Edward Elgar.

Brigham, K. H., De Castro, J. O., \& Shepherd, D. A. (2007). A person-organization fit model of owner managers' cognitive style and organizational demands. Entrepreneurship: Theory and Practice, 31(1), 29-51.

Collewaert, V. (2012). Angel investors' and entrepreneurs' intentions to exit their ventures: a conflict perspective. Entrepreneurship Theory and Practice, 36(4), 753-779.

Conner, M., \& Armitage, C. J. (1998). Extending the theory of planned behaviour: a review and avenues for further research. Journal of Applied Social Psychology, 18, 1429-1464.

Connor, M. (2015). Extending not retiring the theory of planned behaviour: a commentary on Sniehotta, Presseau and AraújoSuares. Health Psychology Review, 9, 141-145.

Cowley, P. (2018). The invested investor (1st ed.). Milton Keynes: Lighting Source. 
DeTienne, D. R. (2010). Entrepreneurship exit as a critical component of the entrepreneurial process: theoretical development. Journal of Business Venturing, 25, 203-215.

DeTienne, D. R., \& Cardon, M. S. (2012). Impact of founder experience on exit intentions. Small Business Economics, $38,351-374$.

Edelman, L. F., Manolova, T. S., \& Brush, C. G. (2017). Angel investing: a literature review. Foundations and Trends in Entrepreneurship, 13, 265-439.

Eisenhardt, K.M. (1989). Building Theories from Case Study Research, Academy of Management Review, 14(4), 532-550.

el Bouzaidi, S. (2015). 4. Survey on venture capital financing exit stage. In DeTienne \& K. Wennberg (Eds.), Research handbook of entrepreneurial exit (p. 87).

Fishbein, M., \& Ajzen, I. (1975). Belief, attitude, intention, and behaviour: an introduction to theory and research. Reading: Addison-Wesley.

French, D. P., \& Hankins, M. (2003). The expectancy-value muddle in the theory of planned behaviour - and some proposed solutions. British Journal of Health Psychology, 8, 37-55.

Frey, K., Lüthje, C., \& Haag, S. (2011). Whom should firms attract to open innovation platforms? The role of knowledge diversity and motivation. Long Range Planning, 44(5-6), 397420.

Garg, S., \& Eisenhardt, K. M. (2017). Unpacking the CEO-board relationship: how strategy making happens in entrepreneurial firms. Academy of Management Journal, 60, 1828-1858.

Gaston, R. J. (1989). Finding venture capital for your firm: a complete guide. New York: Wiley.

Go, Beyond. (2019). The GoBeyond investor report: angel investing strategies and portfolio returns. Available at: https://www. gobeyondinvesting.com/wp content/uploads/2019/04/The-GoBeyond-Investor-Report2019.pdf.

Gollwitzer, P. M., \& Oettingen, G. (2015). From studying the determinants of action to analysing its regulation: a commentary on Sniehotta, Presseau and Araújo-Suares. Health Psychology Review, 9, 146-150.

Gregson, G., Mann, S., \& Harrison, R. (2013). Business angel syndication and the evolution of risk capital in a small market economy: evidence from Scotland. Management and Decision Economics, 34(2), 95-107.

Gregson, G., Bock, A. J., \& Harrison, R. T. (2017). A review and simulation of business angel investment returns. Venture Capital, 19(4), 285-311.

Hagger, M. S. (2015). Retired or not, the theory of planned behaviour will always be with us. Health Psychology Review, 9, 125-130.

Harrison, R. T., \& Mason, C. M. (1992). International perspectives on the supply of informal venture capital. Journal of Business Venturing, 7, 459-475.

Harrison, R. T., Don, G., Glancey-Johnson, \& Greig, M. (2010). The early stage risk capital market in Scotland since 2000issues of scale, characteristics and market efficiency. Venture Capital: An International Journal of Entrepreneurial Finance, 12, 211-239.

Harrison, R. T., Botelho, T., \& Mason, C. M. (2016). Patient capital in entrepreneurial finance: a reassessment of the role of business angel investors. Socio-Economic Review. https://doi.org/10.1093/ser/mww024.
Hayward, M., Caldwell, A., Steen, J., Gow, D., \& Liesch, P. (2017). Entrepreneurs' capital budgeting orientations and innovation outputs: evidence from Australian biotechnology firms. Long Range Planning, 50(2), 121-133.

Hjorth, D., Holt, R., \& Steyaert, C. (2015). Entrepreneurship and process studies. International Small Business Journal, 33(6), 599-611.

Karlsen, S. M. F. (2007). The born global-redefined (Doctoral dissertation, Norwegian School of Management).

Kautonen, T., van Gelderen, M., \& Tornikoski, E. T. (2013). Predicting entrepreneurial behaviour: a test of the theory of planned behaviour. Applied Economics, 45, 697-707.

Krueger, N. F., \& Carsrud, A. L. (1993). Entrepreneurial intentions: applying the theory of planned behaviour. Entrepreneurship and Regional Development, 5, 315-330.

Krueger, N. F., Reilly, M. D., \& Carsrud, A. L. (2000). Competing models of entrepreneurial intentions. Journal of Business Venturing, 15(5-6), 411-432.

Landström, H. (1993). Informal risk capital in Sweden and some international comparisons. Journal of Business Venturing, $8(6), 525-561$.

Landström, H. (1998). Informal investors as entrepreneurs: decision-making criteria used by informal investors in their assessment of new investment proposals. Technovation, 18(5), 321-333.

Loehr, J. (2016). Pitch perfect: the exit strategy is key. New York: Westchester Angels http://westchesterangels.com/pitchperfect-the-exit-strategy-is-key/.

Lortie, J., \& Castrogiovanni, G. (2015). The theory of planned behaviour in entrepreneurship research: what we know and future directions. International Entrepreneurship and Management Journal, 11, 935-957.

Lumme, A., Mason, C., \& Suomi, M. (1998). Informal venture capital: investors, investments and policy issues in Finland. Dordrecht: Kluwer.

Macchi, L., \& Bagassi, M. (2014). The interpretative heuristic in insight problem solving. Mind \& Society, 13, 97-108.

Mason, C., \& Botelho, T. (2016). The role of the exit in the initial screening of investment opportunities: the case of business angel syndicate gatekeepers. International Small Business Journal 34,157-175.

Mason, C., \& Botelho, T. (2014). The 2014 Survey of Business Angel Investing in the UK: A Changing Market Place. http://www.gla.ac.uk/media/media_362647_en.p.

Mason, C., \& Harrison, R. (1994). The informal venture capital market in the UK. In A. Hughes \& D. J. Storey (Eds.), Financing small firms (pp. 64-111). London: Routledge.

Mason, C., \& Harrison, R. (2002). Is it worth it? The rates of return from informal venture capital investments. Journal of Business Venturing, 17, 211-236.

Mason, C. M., \& Harrison, R. T. (2003). Auditioning for money: what do technology investors look for at the initial screening stage? Journal of Private Equity, 6(2), 29-42.

Mason, C., \& Harrison, R. (2010). Annual report on the business angel market in the United Kingdom: 2008/09. Department of Business, Innovation and Skills, $88 \mathrm{pp}$.

Mason, C., \& Harrison, R. (2011). Annual report on the business angel market in the United Kingdom: 2009/10. Department of Business, Innovation and Skills, $56 \mathrm{pp}$.

Mason, C., Botelho, T., \& Harrison, R. (2013). The transformation of the business angel market: evidence from Scotland. 
Working paper. Available at: https://doi.org/10.2139 /ssrn.2306653.

Mason, C., Harrison, R., \& Botelho, T. (2015). Business angel exits: strategies and processes. In J. G. Hussain \& J. M. Scott (Eds.), International research handbook on entrepreneurial finance (pp. 102-1124). Cheltenham: Edward Elgar.

Mason, C., Botelho, T., \& Harrison, R. (2016). The transformation of the business angel market: evidence and research implications. Venture Capital: an international journal of entrepreneurial finance., 18(4), 321-344.

Mason, C., Botelho, T., \& Harrison, R. (2019). The changing nature of angel investing: some research implications. Venture Capital: an international journal of entrepreneurial finance, 21(2-3), 177-194.

Maula, A., Autio, E., \& Arenius, P. (2005). What drives microangel investments? Small Business Economics, 25, 459-475.

McDonald, M. B., \& DeGennaro, R. P. (2016). A review of angel investing research: analysis of data and returns in the US and abroad. Studies in Economics and Finance, 33, 716-734.

McKaskill, T. (2009). Invest to exit: a pragmatic strategy for angel and venture capital investors. Melbourne: Breakthrough Publications.

Meglio, O., Destri, A. M. L., \& Capasso, A. (2017). Fostering dynamic growth in new ventures through venture capital: conceptualizing venture capital capabilities. Long Range Planning, 50(4), 518-530.

Meyer, C. B. (2001). A case in case study methodology. Field Methods, 13(4), 329-352.

Miles, M. B., \& Huberman, A. M. (2003). Analyse des données qualitatives. De Boeck Supérieur.

Miller, C. C., Cardinal, L. B., \& Glick, W. H. (1997). Retrospective reports in organizational research: a reexamination of recent evidence. Academy of Management Journal, 40(1), 189-204.

Montalvo, C. (2006). What triggers change and innovation? Technovation, 26(3), 312-323.

Munari, F., \& Toschi, L. (2014). Running ahead in the nanotechnology gold rush. Strategic patenting in emerging technologies, Technological Forecasting and Social Change, 83, 194-207.

Neergaard, H., \& Ulhøi, J. P. (2007). Handbook of qualitative research methods in entrepreneurship. Cheltenham: Edward Elgar Publishing.

Peters, B. (2009). Early exits: exit strategies for entrepreneurs and angel investors (but maybe not venture capitalists). Coquitlam: Meteor Bytes Data Management.

Politis, D. (2008). Business angels and value-added: what do we know and where do we go? Venture Capital: An International Journal of Entrepreneurial Finance, 10(2), 127-147.

Pratt, M. G. (2008). Fitting oval pegs into round holes: tensions in evaluating and publishing qualitative research in top-tier North American journals. Organizational Research Methods, 11, 481-509.

Puhakka, H. (2017). The role of accounting in making sense of post-acquisition integration. Scandinavian Journal of Management, 33(1), 12-22.

Ramos-Rodriguez, A., Medina-Garrido, J., Lorenzo-Gomez, J., \& Ruiz-Navarro, J. (2010). What you know or who you know? The role of intellectual and social capital in opportunity recognition. International Small Business Journal, 28(6), 566-582.

Rhodes, R. E. (2015). Will the new theories (and theoreticians!) please stand up? A commentary on Sniehotta, Presseau and Araújo-Suares. Health Psychology Review, 9, 156-159.

Rowley, J. (2002). Using case studies in research. Management Research News, 25(1), 16-27.

Ryan, G., \& Bernard, H. R. (2000). Data management and analysis methods. In N. Denzin \& Y. Lincoln (Eds.), Handbook of qualitative research (2nd ed., pp. 769-802). Thousand Oaks: Sage.

Schlaegel, C., \& Koening, M. (2014). Determinants of entrepreneurial intent: a meta-analytical test and integration of competing models. Entrepreneurship Theory and Practice, 38, 291-332.

Schwab, J. J. (1962). The teaching of science as enquiry. Cambridge: Harvard University Press.

Schwab, J. J. (1974). The concept of the structure of a discipline. In E. W. Eisner \& E. Vallance (Eds.), Conflicting conceptions of curriculum. Berkeley: McCutchan (First published 1962).

Schwarzer, R. (2015). Some retirees remain active: A commentary on Sniehotta, Presseau and Araújo-Soares. Health Psychology Review, 9, 138-140.

Shih, Y.-Y., \& Fang, K. (2004). The use of a decomposed theory of planned behaviour to study internet banking in Taiwan. Internet Research, 14, 213-223.

Simon, H. A. (1990). Invariants of human behaviour. Annual Review of Psychology, 41, 1-19.

Sniehotta, F. F., Presseau, J., \& Araújo-Suares, V. (2014). Time to retire the theory of planned behaviour. Health Psychology Review, 8, 1-7.

Spicer, A. (2008). What do OB tools and practices do? In S. R. Clegg \& C. L. Cooper (Eds.), The SAGE handbook of organizational behaviour: volume 2: macro approaches (pp. 4152). Thousand Oaks: Sage.

Stake, R. E. (2005). Case studies. In N. K. Denzin \& Y. S. Lincoln (Eds.), The Sage handbook of qualitative research. Sage.

Taylor, S., \& Todd, P. (1995). decomposition and crossover effects in the theory of planned behaviour: a study of consumer adoption intentions. International Journal of Research in Marketing, 12, 137-155.

Tenca, F., Croce, A., \& Ughetto, E. (2018). Business angels research in entrepreneurial finance: a literature review and research agenda. Journal of Economic Surveys, 32(5), 1384 1413.

Vaivio, J. (2008). Qualitative management accounting research: rationale, pitfalls and potential. Qualitative Research in Accounting \& Management, 5(1), 64-86.

Van Osnabrugge, M. (1998). Do serial and non-serial investors behave differently?: an empirical and theoretical analysis. Entrepreneurship Theory and Practice, 22(4), 23-42.

Van Osnabrugge, M. (2000). A comparison of business angel and venture capitalist investment procedures: An agency theorybased analysis. Venture Capital: An International Journal of Entrepreneurial Finance, 2(2), 91-109.

Vissa, B. (2011). A matching theory of entrepreneurs' tie formation intentions and initiation of economic exchange. Academy of Management Journal, 54(1), 137-158.

Wallmeroth, J., Wirtz, P., \& Groh, A. P. (2018). Venture capital, angel financing, and crowdfunding of entrepreneurial 
ventures: a literature review. Foundations and Trends® in. Entrepreneurship, 14, 1-129.

Wennberg, K., \& DeTienne, D. R. (2014). What do we really mean when we talk about 'exit'? A critical review of research on entrepreneurial exit. International Small Business Journal, 32(1), 4-16.

Wennberg, K., Wiklund, J., DeTienne, D. R., \& Cardon, M. S. (2010). Reconceptualising entrepreneurial exit: divergent exit routes and their drivers. Journal of Business Venturing, 25, 361-375.

Wetzel Jr., W. E. (1981). Informal risk capital in New England. In K. H. Vesper (Ed.), Frontiers of entrepreneurship research 1981. Wellesley: Babson College.

Wetzel Jr., W. E. (1983). Angels and informal risk capital. Sloan Management Review, 24(4), 23-34.

Wiltbank, R. E. (2009). Siding with the angels: business angel investing-promising outcomes and effective strategies. Research report for National Endowment for Science,
Technology and the Arts and British Business Angels Association. London: NESTA.

Wiltbank, R. E., \& Boeker, W. (2007). Returns to angel investors in groups. Kansas City: Kauffman Foundation.

Wiltbank, R., Read, S., Dew, N., \& Sarasvathy, S. D. (2009). Prediction and control under uncertainty: outcomes in angel investing. Journal of Business Venturing, 24(2), 116-133.

Yin, R. K. (2014). Case study research: design and methods. Sage.

Zhang, J. J., Baden-Fuller, C., \& Pool, J. K. (2011). Resolving the tensions between monitoring, resourcing and strategizing: structures and processes in high technology venture boards. Long Range Planning, 44(2), 95-117.

Publisher's note Springer Nature remains neutral with regard to jurisdictional claims in published maps and institutional affiliations. 